\title{
Prevalence of Bovine Viral Diarrhea Virus in Aborted Bovine Fetuses in Korea
}

\author{
Kyunghyun Lee, Eun-Jin Choi ${ }^{*}$ Ji-Youl Jung, Yeonhee Kim, Hyunkyoung Lee, Ji-Hyeon Kim and Byungjae So
}

Animal Disease Diagnostic Division, Animal and Plant Quarantine Agency (APQA), The Ministry of Agriculture, Food and Rural Affairs (MAFRA), 177 Hyeoksin-ro, Gimcheon-si, Gyeongsangbuk-do, 39660, Republic of Korea

"Corresponding author: Eun-Jin Choi, Animal Disease Diagnostic Division, Animal and Plant Quarantine Agency (APQA), The Ministry of Agriculture, Food and Rural Affairs (MAFRA), 177 Hyeoksin-ro, Gimcheon-si. Gyeongsangbuk-do, 39660, Republic of Korea, Tel: +82-54-912-0461; Fax: +82-54-912-0465; E-mail: choiej@korea.kr

Rec date: February 28, 2018; Acc date: March 07, 2018; Pub date: March 09, 2018

Copyright: ( 2018 Lee K, et al. This is an open-access article distributed under the terms of the Creative Commons Attribution License, which permits unrestricted use, distribution, and reproduction in any medium, provided the original author and source are credited.

\begin{abstract}
Several efforts have been made to eradicate bovine viral diarrhea (BVD) in Korea. However, there is still insufficient information on how the BVD virus (BVDV) affects bovine abortion. In this study, we investigated the prevalence of BVDV, and age of fetuses with BVDV infection in 350 aborted fetuses from 314 farms submitted to the Animal and Plant Quarantine Agency in Korea from 2008-2017. Histopathologically, all fetal tissues were autologous, or had no specific lesions. BVDV was detected in $83(23.7 \%)$ fetuses from $77(24.5 \%)$ farms by reverse transcription-polymerase chain reaction and revealed more than $30 \%$ higher detection rates in Chungnam and Gyeongbuk provinces compared to other regions, based on both total data and farm-associated analyses. Estimated age of fetuses with BVDV infection by converting the measured crown-rump length into fetal age showed that most cases occurred with abortions being induced during fetal period considered to be middle and late stage abortions. These results suggest that in order to successfully eradicate BVD in Korea, control programs such as vaccination and enhanced biosecurity should be applied to prevent fetal infections.
\end{abstract}

Keywords: Abortion; Bovine Viral Diarrhea Virus (BVDV); Cattle; Fetus; Korea

\section{Introduction}

Bovine viral diarrhea virus (BVDV) is an important cattle pathogen that causes serious economic losses worldwide [1-3]. BVDV affects the respiratory, reproductive, and gastrointestinal systems. Diseases that affect the reproductive system that are caused by BVDV in cattle include fertilization failure, embryonic death, abortion, mummification, stillbirth, congenital defects, and calves born persistently infected [4].

BVDV is classified in vitro into one of two biotypes, cytopathic (CPBVDV) or noncytopathic (NCP-BVDV), based on effects on cell culture [5]. Through genetic sequencing, BVDV can be further classified according to one of two major genotypes: type 1 and type 2 . There are currently 11 recognized sub genotypes of BVDV type 1 , and two sub genotypes of type 2 [6-8]. Two biotypes and two genotypes of BVDV have been isolated, and the seroprevalence of BVDV has been measured at $72.2 \%$; indicating that BVDV is prevalent nationwide in bovine herds in Korea [9-12].

Abortion leads to severe economic losses in the cattle industry; however, it is difficult to identify the exact causes of abortion. It is known that the diagnostic rate of the causes of abortion varies from 5 to $90 \%$, based on examination of samples submitted to veterinary laboratories worldwide [13]. However, more than $90 \%$ of abortions, in which the cause is determined, are assigned to infection. The infectionrelated causes of abortion in cattle include bacteria, fungi, protozoans, and viruses. Viruses include BVDV, bovine herpesvirus-1, Akabane virus, Aino virus, and Chuzan virus, among others. Diagnosis of BVDV in aborted bovine fetuses has been made using various methods such as histopathological examination, detection of antibody in fetal fluids, seroconversion of mother cows, and detection of viral antigen in fetal tissues.

Currently, the Korean government and cattle breeders are highly interested in the eradication of BVD. In order to achieve this, it is important to determine BVD-related occurrence rates, biological parameters of infection and transmission, and environmental conditions of significance. However, BVD studies have focused mainly on seroprevalence, genotyping, genetic characterization of BVDV isolates, and the prevalence of BVDV persistent infection of cattle in Korea [9-12,14,15]. Although bovine abortion caused by BVDV was investigated in 1999 by Lee et al. for one area, and in the early 2000s by Park et al. without regional information being reported, these findings are limited in their application to understanding the recent nationwide situation in Korea $[9,16]$.

In the current report, we describe the detection rate of BVDV, and age of fetuses with BVDV infection in aborted bovine fetuses submitted to the Animal and Plant Quarantine Agency (APQA) for the entire country of Korea over the past 10 years. This type of data is crucial for the rational development of strategies for preventing BVDV-induced abortions and ultimately for its eradication from Korean cattle.

\section{Materials and Methods}

\section{Preparation of samples}

Three hundred and fifty aborted fetuses from 314 cattle farms were submitted to the APQA in 2008-2017 to determine the cause of abortion. The lung, liver, heart, spleen, kidney, intestine, ear, muscle, tongue, and brain tissues from the fetuses were routinely collected and processed using previously described methods [9,17]. The fetal tissues were chopped, homogenized, and prepared as $10 \%$ suspensions (v/v) in 
Page 2 of 4

$0.8 \%$ saline. The suspensions were centrifuged for $15 \mathrm{~min}$ at $3,000 \times \mathrm{g}$ and the supernatants stored at $-80^{\circ} \mathrm{C}$ until use. All organs or tissues used for histopathologic examination were fixed in $10 \%$ neutral buffered formalin and embedded in paraffin wax. The embedded tissues were sectioned and subsequently stained with hematoxylin and eosin.

\section{Reverse transcription-polymerase chain reaction (RT-PCR)}

All fetal samples were individually tested. Viral RNA was extracted from samples using an RNeasy Mini Kit (Qiagen, Hilden, Germany) according to the manufacturer's instructions and stored at $-80^{\circ} \mathrm{C}$ until analyzed. The isolated RNA was used as template and reverse transcribed into complementary DNA (cDNA) at $45^{\circ} \mathrm{C}$ for $30 \mathrm{~min}$. A segment of the $5^{\prime}$-untranslated region (UTR) of pestivirus was specifically amplified by PCR using primers 324 and 326, as previously described $[11,18]$. The forward (324) and reverse (326) primers used were 5'-ATG CCC WTA GTA GGA CTA GCA-3' (W=A or T), and 5'TCA ACT CCA TGT GCC ATG TAC- $3^{\prime}$, respectively. The predicted size of the amplified PCR products was 288 base pair (bp). For amplification, the PCR cycling profile included denaturation at $94^{\circ} \mathrm{C}$ for $5 \mathrm{~min}$, followed by 30 sequential cycles of $94^{\circ} \mathrm{C}$ for $30 \mathrm{~s}, 55^{\circ} \mathrm{C}$ for 30 $\mathrm{s}$, and $72^{\circ} \mathrm{C}$ for $1 \mathrm{~min}$. The RT-PCR products were analyzed by electrophoresis on $1.5 \%$ agarose gels and visualized using ethidium bromide.

\section{Estimation of fetal age}

To estimate age of fetuses with BVDV, the fetal crown-rump length (CRL) was measured and converted to fetal age using the formula according to recommendations for standardizing bovine reproduction terms established by the Committee on Bovine Reproductive Nomenclature [19]. The fetal period was divided into early abortion (42-120 days of gestation), middle abortion (120-180 days of gestation), late abortion (180-260 days of gestation), and premature delivery ( $>260$ days of gestation), according to the same recommendations.

\section{Results}

Histopathological analyses provided minimal positive findings. For fetuses that had undergone severe autolysis and decomposition between the time of abortion and tissue processing, it was difficult to observe tissue lesions. Meanwhile, microscopic evaluation of the relatively fresh fetuses did not reveal any BVDV-specific lesions.

From the 314 farms that submitted samples that were analyzed in the study, BVDV was detected in fetuses from 77 (24.5\%) of them. The percentage of farms testing positive from 2008 through 2017 varied from $10.5-75 \%$ for any given year (Table 1). Among 350 aborted fetuses analyzed by RT-PCR, BVDV was detected in 83 (23.7\%). As seen in Table 1, the prevalence of BVDV in individual years, independent of the farm-source, varied from 3-24 positive fetuses, with a range of only $11 \%$ of the fetuses being positive in 2017 , but as many as $72.7 \%$ of the tested fetuses being PCR positive in 2008 .

\begin{tabular}{|c|c|c|c|c|}
\hline \multirow[b]{2}{*}{ Year } & \multicolumn{2}{|l|}{ Farm $^{1}$} & \multicolumn{2}{|l|}{ Total $^{2}$} \\
\hline & No. tested ${ }^{3}$ & $\begin{array}{l}\text { No. positive } \\
(\%)^{4}\end{array}$ & No. tested & $\begin{array}{l}\text { No. positive } \\
(\%)\end{array}$ \\
\hline 2008 & 32 & $24(75.0)$ & 33 & $24(72.7)$ \\
\hline
\end{tabular}

\begin{tabular}{|l|l|l|l|l|}
\hline 2009 & 31 & $12(38.7)$ & 31 & $12(38.7)$ \\
\hline 2010 & 26 & $9(34.6)$ & 30 & $10(33.3)$ \\
\hline 2011 & 20 & $3(15.0)$ & 20 & $3(15.0)$ \\
\hline 2012 & 16 & $3(18.8)$ & 19 & $4(21.1)$ \\
\hline 2013 & 18 & $3(16.7)$ & 21 & $4(19.0)$ \\
\hline 2014 & 24 & $5(20.8)$ & 27 & $5(18.5)$ \\
\hline 2015 & 24 & $4(16.7)$ & 27 & $4(14.8)$ \\
\hline 2016 & 28 & $4(14.3)$ & 33 & $5(15.2)$ \\
\hline 2017 & 95 & $10(10.5)$ & 109 & $12(11.0)$ \\
\hline Total & 314 & $77(24.5)$ & 350 & $83(23.7)$ \\
\hline
\end{tabular}

Table 1: Detection of bovine viral diarrhea virus (BVDV) in aborted bovine fetuses. ${ }^{1}$ Data represent findings classified by individual farms that submitted aborted fetuses to the APQA for analysis and included in the study. ${ }^{2}$ Data compiled as total fetuses submitted to the APQA for analysis and included in the study. ${ }^{3}$ The total number of aborted fetuses analyzed by reverse transcription-polymerase chain reaction (RT-PCR) for the specific detection of BVDV. ${ }^{4}$ The total number of submitted fetuses analyzed by RT-PCR for the specific detection of BVDV and the corresponding percentage.

Whether considering data at the farm level or as individual providences independent of the farm, the prevalence of BVDV was highest in Chungnam Province (36.8\%) when analysis was restricted to only regions with 10 or more fetuses. This was followed by Gyeongbuk (34.8\%), Gangwon (23.9\%), Jeonnam (17.4\%), and Jeonbuk (13.9\%) (Table 2).

\begin{tabular}{|l|l|l|l|l|}
\hline \multirow{2}{*}{ Province } & \multicolumn{2}{|l|}{ Farm $^{1}$} & \multicolumn{2}{l|}{ Total $^{2}$} \\
\cline { 2 - 5 } & $\begin{array}{l}\text { No. } \\
\text { tested }\end{array}$ & $\begin{array}{l}\text { No. positive } \\
(\%)^{4}\end{array}$ & No. tested & $\begin{array}{l}\text { No. positive } \\
(\%)\end{array}$ \\
\hline Gangwon & 61 & $15(24.6)$ & 71 & $17(23.9)$ \\
\hline Chungbuk & 4 & $3(75.0)$ & 5 & $4(80.0)$ \\
\hline Chungnam & 17 & $7(41.2)$ & 19 & $7(36.8)$ \\
\hline Jeonbuk & 32 & $5(15.6)$ & 36 & $5(13.9)$ \\
\hline Jeonnam & 21 & $4(19.0)$ & 23 & $4(17.4)$ \\
\hline Gyeongbuk & 62 & $22(35.5)$ & 69 & $24(34.8)$ \\
\hline Gyeongnam & 3 & $3(100.0)$ & 3 & $3(100.0)$ \\
\hline Unknown & 111 & $16(14.4)$ & 121 & $17(14.0)$ \\
\hline Total & 314 & $77(24.5)$ & 350 & $83(23.7)$ \\
\hline
\end{tabular}

Table 2: Regional distribution of aborted bovine fetuses with bovine viral diarrhea virus (BVDV). ${ }^{1}$ Data represent findings classified by individual farms that submitted aborted fetuses to the APQA for analysis and included in the study. ${ }^{2}$ Data compiled as total fetuses submitted to the APQA for analysis and included in the study. ${ }^{3}$ The total number of aborted fetuses analyzed by reverse transcriptionpolymerase chain reaction (RT-PCR) for the specific detection of 
BVDV. ${ }^{4}$ The total number of submitted fetuses analyzed by RT-PCR for the specific detection of BVDV and the corresponding percentage.

The CRL was measured for 66 of the 83 fetuses infected with BVDV and ranged from 20 to $115 \mathrm{~cm}$. Conversion of the CRLs to estimated ages resulted in the fetuses ranging from 97.5 to 289.8 days of gestation at the time when they were aborted (Table 3). Sixty-five of the measured fetuses were estimated to have been aborted during either the early, middle, or late gestational period. Only one calf was delivered at a gestational age considered to be a premature birth; a stillborn between 260 days and full term.

\begin{tabular}{|l|l|l|l|}
\hline $\begin{array}{l}\text { Crown-rump } \\
\text { length of } \\
\text { fetus (cm) }\end{array}$ & No. positive ${ }^{1}$ (\%) & $\begin{array}{l}\text { Estimated fetal } \\
\text { age (days) }\end{array}$ & $\begin{array}{l}\text { Estimated fetal } \\
\text { period }^{2}\end{array}$ \\
\hline $20-25$ & $4(6.1)$ & $97.5-113$ & Early \\
\hline $31-48$ & $27(40.9)$ & $130.9-176.7$ & Middle \\
\hline $50-83$ & $34(51.5)$ & $181.6-249.2$ & Late \\
\hline 115 & $1(1.5)$ & 289.8 & Premature delivery \\
\hline
\end{tabular}

Table 3: Estimation of fetal age and period of aborted fetus with bovine viral diarrhea virus (BVDV). ${ }^{1}$ The total number of aborted fetuses analyzed by reverse transcription polymerase chain reaction (RT-PCR) for the specific detection of BVDV. ${ }^{2}$ Fetal period: Early (days 42-119), Middle (days 120-179), Late (days 180-260), and Premature delivery (>260 days of gestation).

\section{Discussion}

Reproductive problems are common consequences of BVDV infection in cattle [4]. Abortion is always a possibility when in utero BVDV infection occurs [5]. When the virus is infected in a pregnant cow, it can easily pass through the placenta following the viremia condition and infect the embryo or fetus [20]. If the virus is infected at embryonic period, the dead embryo may be unobserved directly. Infection of the fetal period results in direct invasion of the fetus itself and secondary endometritis leading in death. Detecting antibody in a fetus, same as in an unsuckled neonate, indicates that intrauterine infection has occurred, but its diagnostic significance in regard to abortion is not clear. The recovery of virus from the fetus, or demonstration of viral antigen within fetal tissues, is only suggestive for a diagnosis of BVDV-induced abortion [12]. A routinely used diagnostic method for BVDV is RT-PCR amplification [4,21]. We identified an overall average of $23.7 \%$ BVDV infections in 350 aborted fetuses collected nationwide from 314 cattle farms in Korea over the past 10 years. BVDV demonstrated similar detection rates for farms and overall data in aborted fetuses collected yearly. Similar findings are reported by Murray in which $27 \%$ of 150 aborted fetuses from North West England tested positive for BVDV infection [22]. However, these results are much higher than those previously reported in Korea. The proportion of aborted bovine fetuses related to BVDV infection was reported as $6.8 \%(n=249)$ in the early 2000 s, and $8.2 \%(n=73)$ from a single region in $1999[9,16]$. The differences in BVDV positivity in aborted fetuses between our study and the previous reports may be due to the time of sampling, or regional factors. We were unable to make direct comparisons between the studies because the vaccination history was not presented in the reports. It can be concluded that BVDV infections in the late 2000s increased significantly relative to the turn of the century. In addition, it seems that several measures for controlling BVD have been effective, based on the reduced prevalence of BVDV-positive fetuses among those tested (Table 1); further analysis is needed to prove this point.

There have been no previous studies on the occurrence of BVDVrelated abortion in each region in Korea. The detected regional rates of BVDV were much higher in Chungnam and Gyeongbuk provinces compared to in other regions, except for $14.0 \%$ of the total samples that were not identified regarding their areas of origin, and for provinces that provided only a small number of samples. The reason for the high rates in these two provinces is thought to be the large number of cattle breeding herds, and the high interest in requesting laboratory diagnosis to identify the cause of abortions.

The primary negative reproductive issue caused by disease in pregnant cattle is loss of the fetus, which can be divided into three types; embryonic death, abortion, and stillbirth. Abortion in cattle is commonly defined as a loss of the fetus between the gestational age of 42 days and approximately 260 days [19]. Pregnancies lost before 42 days are usually referred to as early embryonic deaths, whereas a calf that is born dead between 260 days and full term is defined as stillbirth of premature delivery. CP-BVDV has been found to be the cause of, or at least associated with, abortion at most stages of gestation, and abortion in the mid or last trimester may be a result of NCP-BVDV [5]. Oem et al. reported the results of BVDV genotyping of specimens from stools, brains, and aborted fetuses of cattle suspected of BVDV infection during the period of 2007-2008 [11]. They suggest that both BVDV-1 and -2 are prevalent in Korea, and that BVDV-2 is highly infectious, especially to fetuses resulting in abortion. Our study did not investigate the biotype or genotype of BVDV, but our findings demonstrated the time of abortion being consistent with those previously reported. Estimating age of fetuses with BVDV infection by converting the measured crown-rump length into fetal age showed that all cases except one were during the abortion period. The one fetus not within the gestational classification for abortion was evaluated as 289.8 days of gestation. We consider this to be consistent with a previous report stating that in some instances BVDV may infect the fetus several weeks, or even months, before abortion is induced [5].

Four basic steps are known for effective prevention of BVDV infection: improvement of herd immunity through immunization, identification and removal of persistently infection animals within the herd, screening of new animals before introduction into the herd, and implementation of biosecurity practices [5]. The goals to improve herd immunity are to reduce or prevent acute disease and fetal infection, and to strengthen colostrum immunity. The efficacy of BVDV vaccines for the prevention of fetal infection was uncertain, but recently it has been proven that vaccination prior to breeding gives rise to a considerable fetal protection, though not $100 \%$ [20]. Overall, our results and those of others indicate that in order to successfully eradicate BVD from Korean cattle, control programs to prevent fetal exposure to BVDV should be applied.

\section{Acknowledgements}

This study was supported by a grant from the Animal and Plant Quarantine Agency (APQA), the Ministry of Agriculture, Food and Rural Affairs (MAFRA), Republic of Korea (Project Code No. B-1543069-2017-18-07). 
Citation: Lee K, Choi EJ, Jung JY, Kim Y, Lee H, et al. (2018) Prevalence of Bovine Viral Diarrhea Virus in Aborted Bovine Fetuses in Korea. J Vet Sci Technol 9: 520. doi:10.4172/2157-7579.1000520

Page 4 of 4

\section{References}

1. Baker JC (1987) Bovine viral diarrhea virus: a review. J Am Vet Med Assoc 190: 1449-1458.

2. Houe H (1999) Epidemiological features and economical importance of bovine viral diarrhoea virus (BVDV) infections. Vet Microbiol 64: 89-107.

3. Wilson DJ, Baldwin TJ, Kelly EJ, Wettere AV, Hullinger G, et al. (2016) Prevalence of bovine viral diarrhea virus in bovine samples from the intermountain west of the USA - comparison between age, sex, breed and diagnostic methods. J Vet Sci Technol 7: 326.

4. Radostits OM, Gay CC, Hinchcliff KW, Constable PD (2007) Bovine virus diarrhea virus, mucosal disease. Bovine pestivirus disease complex. Veterinary medicine. 10th edn. Saunders Elsevier, pp: 1248-1277.

5. Divers TJ, Peek SF (2008) Infectious Diseases of the gastrointestinal tract. Rebhun's diseases of dairy cattle. 2nd edition, Saunders Elsevier, pp: 258-273.

6. Ridpath JF, Bolin SR, Dubovi EJ (1994) Segregation of bovine vira diarrhea virus into genotypes. Virol 205: 66-74.

7. Ridpath JF, Bolin SR (1998) Differentiation of types 1a, $1 \mathrm{~b}$ and 2 bovine viral diarrhea virus (BVDV) by PCR. Mol Cell Probes 12: 101-106.

8. Vilcek S, Paton DJ, Durkovic B, Strojny L, Ibata G, et al. (2001) Bovine viral diarrhea virus genotype 1 can be separated into at least eleven genetic groups. Arch Virol 146: 99-115.

9. Park JS, Moon HJ, Lee BC, Hwang WS, Yoo HS, et al. (2004) Comparative analysis on the 5-untranslated region of bovine viral diarrhea virus isolated in Korea. Res Vet Sci 76: 157-163.

10. Yang DK, Kim BH, Kweon CH, Park JK, Kim HY, et al. (2007) Genetic typing of bovine viral diarrhea viruses (BVDV) circulating in Korea. J Bacteriol Virol 37: 147-152.

11. Oem JK, Hyun BH, Cha SH, Lee KK, Kim SH, et al. (2009) Phylogenetic analysis and characterization of Korean bovine viral diarrhea viruses. Vet Microbiol 139: 356-360.

12. Cho JS, Kim GD, Park HJ, Lim YS, Hong SH, et al. (2013) Prevalence for persistently infected cattle with bovine viral diarrhea virus in Korea. Korean J Vet Sci 36: 105-110.
13. Schlafer DH, Foster RA (2016) Female genital system. In: Maxie MG (Ed) Jubb, Kennedy, and Palmer's pathology of domestic animals. 6th ed. Elsevier, pp: 399-441.

14. Bae YC, Kim HY, Park JW, Yoon SS, Woo GH, et al. (2007) Prevalence for persistent infection with bovine viral diarrhea virus in Korean native calves. Korean J Vet Res 47: 163-167.

15. Song MC, Choi KS (2009) Phylogenetic analysis of bovine viral diarrhea virus from nasal swab sample of persistently infected cattle in republic of Korea. J Vet Clin 26: 582-585.

16. Lee BC, Kim DY, You HS, Kim SK, Lee HS, et al. (1999) Clinical aspect of bovine abortion in Korea. I. Clinical aspect of bovine abortion in Kyunggi-do area. J Emb Trans 14: 211-217.

17. Han YJ, Kwon YJ, Lee KH, Choi EJ, Choi KS (2016) Experimental infection with non-cytopathic bovine viral diarrhea virus 1 in mice induces inflammatory cell infiltration in the spleen. Arch Virol 161: 2527-2535.

18. Vilcek S, Herring AJ, Herring JA, Nettleton PF, Lowings JP, et al. (1994) Pestivirus isolated from pigs, cattle and sheep can be allocated into at least three genogroups using polymerase chain reaction and restriction endonuclease analysis. Arch Virol 136: 309-323.

19. Committee on Bovine Reproductive Nomenclature (1972) Recommendations for standardizing bovine reproduction terms. Cornell Vet 62: 216-237.

20. Newcomer BW, Chamorro MF, Walz PH. (2017) Vaccination of cattle against bovine viral diarrhea virus. Vet Microbiol 206: 78-83.

21. Ridpath JF, Hietala SK, Sorden S, Neill JD (2002) Evaluation of the reverse transcription-polymerase chain reaction/probe test of serum samples and immunohistochemistry of skin sections for detection of acute bovine viral diarrhea infections. J Vet Diagn Invest 14: 303-307.

22. Murray RD (1991) Lesions in aborted fetuses and placenta associated with bovine viral diarrhea virus infection. Arch Virol Suppl 2: 217-224. 